\title{
EVALUATION OF MIND MAPS AS A LEARNING TOOL IN MICROBIOLOGY FOR MEDICAL STUDENTS
}

\author{
Pooja Sarmah ${ }^{1}$, Hemavathi², Sharvani R33, Poornima Shenoy 4
}

${ }^{1}$ Associate Professor, Department of Microbiology, Sapthagiri Institute of Medical Sciences and Research Centre, Bangalore. 2 Professor and HOD, Department of Microbiology, Sapthagiri Institute of Medical Sciences and Research Centre, Bangalore. ${ }^{3}$ Assistant Professor, Department of Microbiology, Sapthagiri Institute of Medical Sciences and Research Centre, Bangalore. ${ }^{4}$ Professor, Department of Microbiology, Sapthagiri Institute of Medical Sciences and Research Centre, Bangalore.

\section{ABSTRACT}

\section{BACKGROUND}

Medical students are exposed to various teaching \& learning methods. Good methods provide meaningful and active learning. Types of learners are visual, aural, kinaesthetic, etc. Understanding of concepts \& remembering is better when whole brain is involved as with mind maps.

The aim of the study was to assess the effectiveness of mind maps as a learning tool and to know the perception of mind maps among medical students.

\section{MATERIALS AND METHODS}

One hundred II year MBBS students were selected. A pre-test was taken on T. trichiura followed by lecture. The students were divided into two groups; A (with 49 students), and B (with 51 students). A class on mind mapping was taken for batch B. Both batches were asked to revise T. trichiura but batch B were asked to use the aid of mind maps. Later post-test was given. Students' perception on mind map was analysed.

\section{RESULTS}

In the pre-test for groups A\&B, none of them scored 50\% marks. In the post-test groups; group A-33 out of 49 scored above $50 \%$ while all 51 of group B scored above 50\%. The post-test scores between groups A\&B were compared and found statistically significant. The feedback form was also analysed statistically and found to be valid. Majority of students in group B agreed that mind maps were useful tools for revision, generation, visualisation and organisation of information, it also helped in knowledge acquisition and connect concepts.

\section{CONCLUSION}

Mind maps are effective tools for active learning and aid in short term memory and majority of the students also perceive mind maps as a useful tool for learning.

\section{KEYWORDS}

Microbiology, Medical Education, Mind Maps, Medical Students.

HOW TO CITE THIS ARTICLE: Sarmah P, Hemavathi, Sharvani R, et al. Evaluation of mind maps as a learning tool in microbiology for medical students. J. Evolution Med. Dent. Sci. 2017;6(1):27-29, DOI: 10.14260/Jemds/2017/8

\section{BACKGROUND}

A student in a medical college is taught various subjects using different teaching \& learning methods (TL methods) for example; didactic lectures, practical classes, clinical postings, case based learning, problem based learning, web based learning, etc.[1] Each of the above methods have their own uses and limitations. With some methods a student becomes an active learner and with some they become passive learners.[2] A good method is the one which aims at students to acquire active and meaningful learning, i.e. the ability to understand and relate relevant medical concepts by linking them to prior knowledge and also inculcate critical thinking;

Financial or Other, Competing Interest: None.

Submission 28-11-2016, Peer Review 23-12-2016,

Acceptance 28-12-2016, Published 02-01-2017.

Corresponding Author:

Dr. Pooja Sarmah,

\# 245 NTI Layout, $8^{\text {th }}$ Main,

Ganapati Temple Road,

Vidyaranyapura,

Bangalore- 560097

E-mail:drpoojasarmah@gmail.com

DOI: $10.14260 /$ jemds $/ 2017 / 8$ clinical reasoning and clinical problem solving. ${ }^{[3,4]}$ The vision 2015 document of the Medical Council of India states the need of new learning strategies to inculcate active learning.[5] Among students there are various types of learners- visual, aural, kinaesthetic, verbal, logical, social and solitary.[6] So when information reaches the student by the various TL methods, the ability of the student to understand and grasp the information may vary. Right brain is the creative part \& the left brain is the logical part.[7] Hence, TL methods which provides stimulation of both the sides of the brain lead to meaningful information representation and create maximum understanding and memory. Various TL methods like the concept maps and mind maps emphasise on this. ${ }^{[8]}$

Mind maps were created by Tony Buzan in the 1970s and he got his inspiration from the various texts of the grand master, Leonardo Da Vinci.[9] It is an innovative way of thinking called as radiant thinking. It is an external mirror of what goes on inside the brain.[9] It is a powerful graphical technique wherein the idea or topic of discussion of the mind map is placed at the centre of a plain sheet of paper in landscape format, and the keywords branch out in a divergent pattern organically from 1 o'clock position in clockwise direction. Hence, data gets hierarchically organised with the main topic at the centre, and the details at the periphery. Smaller branches project from the subtopics with 
more details in a progressive manner.[10] Multiple colours, diagrams, symbols, figures are used to represent data instead of simple words. Information is organised in a non-linear manner as compared to linear note making.[11]

Medical students have to grasp wide amount of information. Many times it becomes overwhelming and confusing for the student on the relevance, importance and applicability of various topics.[12]

Hence, in such situations, mind maps offer an effective self-learning tool which promotes active and meaningful learning and focuses on salient features of the topic and also help in understanding and relating concepts.[13]

\section{MATERIALS AND METHODS}

A total of 100 student volunteers of second year MBBS were selected for the study. The objectives of the study were to assess the effectiveness of mind maps as a learning tool for short-term memory and also to know the perception of mind maps as a tool for learning among medical students. The inclusion criteria was to select students who had not covered T. trichiura in theory and the exclusion criteria was students who had covered T. trichiura in theory.

A pre-test of 20 marks was given on $\mathrm{T}$. trichiura, which was later followed by a 30 minutes lecture class for all the 100 students. The students were later divided into two groups; Group A which included 49 students i.e. the self-study group and group B which had 51 students i.e. the mind mapping group. A class on mind mapping was taken for group B.

Later both the groups were asked to revise the parasitology topic covered. Students of group A revised using their own selected method of learning. Group B students were asked to apply the techniques of mind map and revise and also prepare mind maps. Each group was given 30 minutes for the above activity. All the students were then given a post-test of 20 marks. This was to evaluate the shortterm memory.

Students' perception about the mind maps was determined by giving a standardised self-administered feedback form of Likert's scale of grading with options ranging from strongly agree, agree, neutral, disagree and strongly disagree.

In order to reduce bias, once the study was completed group A was taught the techniques of mind mapping and asked to apply the technique in learning the assigned topic.

Once the study was completed the results were statistically analysed using the paired $t$ test and the independent test. The feedback forms were also statistically analysed. Analysis was done using SPSS. v. 20.0.

\section{RESULTS}

The results of pre-test and post-test of students of group A were analysed. The mean score was 0.75 for pre-test and 10.07 for post-test of a total of 20 marks. The results between both the pre and post-test were compared and found to be statistically significant, with $\mathrm{p}$ value of $0.001 \& \mathrm{t}$ value of 21.52 as shown in Table 1.

The results of pre and post-test of group B were also analysed. The mean score was 1.33 for pre-test \& 14.07 for post-test of a total of 20 marks. The results between both the pre and post-test were compared and found to be statistically significant with $\mathrm{p}$ value of $0.001 \& \mathrm{t}$ value of 36.74 as shown in Table 2.
Pre-test scores were poor for students of both the groups A and B, none of them scored 50\% marks. But during post-test both groups fared better, 33 of 49 students of group A scored $50 \%$ marks while all of 51 students of group B scored $50 \%$ marks. The lowest score of group A was four and highest was 16. Lowest score of group B was 10 and the highest was 18.5.

The post-test scores between group A and B were compared and the results were significant with $\mathrm{p}$ value of 0.001 \& $\mathrm{t}$ value 7.484 as shown in Table 3 .

Feedback form regarding mind mapping from the group B students was also statistically analysed and the results were found to be valid (Figure 1). More than $90 \%$ of the students either strongly agreed or agreed that it was an enjoyable and fun exercise; it helped them in remembering and recalling information; helped in revision and helped to visualise, generate and organise ideas

More than $80 \%$ of the students either strongly agreed or agreed that mind maps helped clear ideas, understand concepts, support knowledge acquisition, connect concepts and improve productivity. They also showed keen interest to use mind maps in other subjects.

However, only around $70 \%$ of the students either strongly agreed or agreed that it helped in building confidence and in improving presentation skills.

\begin{tabular}{|c|c|c|}
\hline $\begin{array}{c}\text { Group A } \\
\mathbf{n = 4 9}\end{array}$ & Mean & Standard Deviation \\
\hline Pre-test & 0.7500 & 0.77055 \\
\hline Post-test & 10.0714 & 2.98390 \\
\hline \multicolumn{2}{|c|}{ Paired t test, p value- $0.001, \mathrm{t}$ value-21.512 } \\
\hline \multicolumn{3}{|c|}{ Table 1. Comparison between Pre \& } \\
Post-test results of Group A \\
\hline
\end{tabular}

\begin{tabular}{|c|c|c|}
\hline $\begin{array}{c}\text { Group B } \\
\mathbf{n = 5 1}\end{array}$ & Mean & Standard Deviation \\
\hline Pre-test & 1.3382 & 1.18830 \\
\hline Post-test & 14.0784 & 2.31381 \\
\hline \multicolumn{2}{|c|}{ Paired t test, p value-0.001 t value-36.748, } \\
\hline \multicolumn{2}{|c|}{ Table 2. Comparison between Pre \& } \\
Post-test results of Group B
\end{tabular}

\begin{tabular}{|c|c|c|c|}
\hline Group & n & Mean & Std. Deviation \\
\hline A & 49 & 10.0714 & 2.98390 \\
\hline B & 51 & 14.0784 & 2.31381 \\
\hline Independent sample test/ unpaired t test- p- $0.001, \mathrm{t}-7.484$ \\
\hline \multicolumn{4}{|c|}{ Table 3. Comparison of Post-test results } \\
between Group A \& B \\
\hline
\end{tabular}

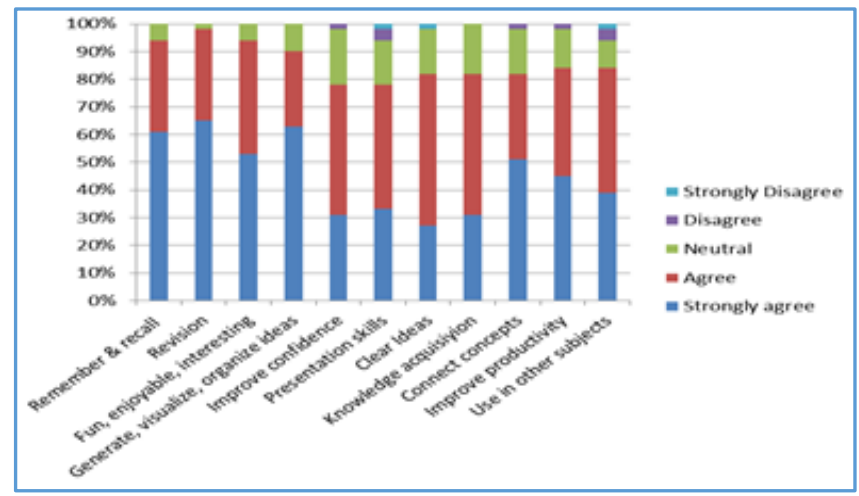

Figure 1. Student's Perception of Mind Maps 


\section{DISCUSSION}

The students of both the groups i.e., self-study group and mind mapping group performed poorly in the pre-test as they were tested against an unfamiliar topic. After taking a theory class on the topic, the self-study group revised on their own but the mind map group used the aid of mind maps to revise, both the groups performed better in the post-test which shows the utility of didactic lecture, self-study and mind maps. However, when the results of post-test of mind map and the self-study group was compared the former fared better showing the utility of mind maps in short-term memory. This was similar to a study by Farrand et al[10] on short-term memory and mind maps; however, a study by Wikramasinghe et al[6] was contrary to our study. Hence, we conclude that mind maps aid students in short-term memory. To our knowledge, this is the first time an attempt has been made to evaluate the effectiveness of mind maps among medical students in the Indian context. More studies are needed to evaluate the relation of mind maps to longterm memory.[7]

Student's perception on mind maps was positive and more than $90 \%$ of them felt it was a fun and enjoyable process. Learning if it is made fun becomes stress free and also stimulates the student to engage better. Mind maps helped them organise, revise and recall data. Using mind maps information regarding the related topic is available in one single sheet of paper. This makes it easy for the student to quickly glance through the figures, diagrams, etc and recall what's been learnt.[14]

More than $80 \%$ of the students opined that mind maps helped them to have clear ideas, understand and connect concepts, support knowledge acquisition and improve productivity. Many were keen on using mind maps for other subjects. This was similar to a study by Wikramasinghe et al.[6] But only around 70\% of the students felt that it helped build confidence; the reason for this was because the results of the pre and post-test were not revealed to them on their performance before their feedback. Hence, they could not assess their performance and build confidence.

\section{CONCLUSION}

There is a need to utilise various teaching-learning strategies which stimulate and enlighten the mind of the student so that they become lifelong learners. Hence, mind maps along with traditional methods will help the student assimilate information in a logical and natural manner. There is a need to move from teacher centred to student centred approach. A medical student learning Microbiology has to remember various bacteria, viruses, fungi \& parasites along with other topics from various other subjects. The information sometimes may get too confusing with too many nomenclatures, diagrams, life cycles, biochemical reactions, etc. Hence, a mind map will help the student to represent important information in relation with one organism in a single sheet of paper which will in turn help the student to quickly glance through the sheet rather than read voluminous texts related to the topic. They also will help the student link concepts and remember better.

\section{Acknowledgement}

We hereby thank Dr Jayanthi.V, Dean, Sapthagiri Institute of Medical Sciences \& Research Centre, Bangalore and Dr Aparna Narasimha, Professor, Department of Pathology and Convenor, Medical Education Department, Sapthagiri Institute of Medical Sciences \& Research Centre, Bangalore, for their encouragement, support and help.

We would also like to thank Dr. Kruthika Gowda, Assistant Professor, Department of Community Medicine, Sapthagiri Institute of Medical Sciences \& Research Centre, Bangalore for her statistical analysis and help.

\section{REFERENCES}

[1] Vaughn L, Baker R. Teaching in medical setting: balancing teaching styles, learning styles and teaching methods. Medical Teacher 2001;23(6):610-2.

[2] Bitran M, Zuniga D, Padilla O, et al. Medical students change in learning styles during the undergraduate programme: from thinking and watching to thinking and doing. Canadian Medical Education Journal 2012;3(2):e86-97.

[3] Daley BJ, Torre DM. Concept maps in medical education: an analytical literature review. Medical education 2010;44(5):440-8.

[4] D'antoni AV, Zipp GP, Oslon VG, et al. Does the mind map learning strategy facilitate information retrieval and critical thinking in medical students? BMC Medical Education 2010;10:61.

[5] Medical council of India. Vision 2015. New Delhi: MCI, 2011.

[6] Wickramasinghe A, Widanapathirana N, Kuruppu O, et al. Effectiveness of mind maps as a learning tool for medical students. South East Asian J Med Edu 2007;1:30-2.

[7] Sperry RW. Hemispheric deconnection and unity in conscious awareness. Scientific American 1968;23(10):723-35.

[8] Ambrose SA, Bridges MW, Di Pietro M, et al. In: How learning works: seven research-based principles for smart learning. San Francisco, CA 2010.

[9] Buzan T. Inventor of mind mapping 2011. Available from: http://www.tonybuzan.com/about /mindmapping/

[10] Farrand P, Hussain F, Hennessy E. The efficacy of the mind map study technique. Medical Education 2002;36(5):426-31.

[11] Zipp G, Maher C. Prevalence of mind mapping as teaching and learning strategy in physical therapy curricula. Journal of the Scholarship of Teaching and Learning 2013;13(5):21-32.

[12] Anderson J, Graham A. A problem in medical education: is there an information overload? Med Educ 1980;14(1):4-7.

[13] Smith R. Strategies for coping with information overload. BMJ 2010;341:c7126.

[14] Guerreo JM, Ramos P. The new application of mind mapping in medicine. iMed Pub Journals 2015;7(4):14. 